Editorial

\title{
Feliz Ano Novo com Klopstock ou Robespierre
}

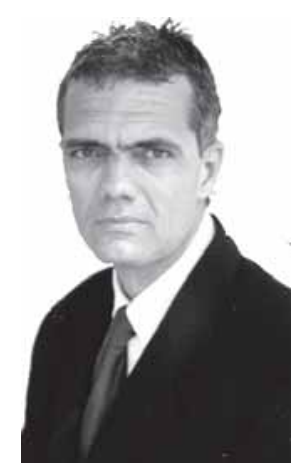

Prof. Dr. Marco Antonio Guimarães da Silva* marco@atlanticaedu.com.br

Mergulhado em um cenário onde predominava a visão de verdejantes e coloridas colinas que se sucediam formando vales de indescritível beleza, experimentava, naquela doce e fresca manhã, uma serenidade digna dos anjos. $O$ que via na natureza e o que sentia criava uma verdadeira mistura entre misticismo e sensibilidade. Podia precisar, sem nenhuma dificuldade, a época e o lugar em que me encontrava: a poética e impetuística Alemanha de Klopstock ${ }^{1}$.

Subitamente, me vi transportado para Place de La Concorde, na França de 1790, assumindo a personalidade de um parlamentar girondino, prestes a ver separada de meu pescoço a minha preciosa cabeça. Tỉnha diante de mim duas importantes figuras daqueles dificeis tempos, as quais me eram muito familiares - o meu editor executivo e o seu sócio - incorporando respectivamente as personagens Maximilien Robespierre e Saint-Just. Estavam para me oferecer indulgência, quando uma chamada telefônica me acordou. O sonho tornou-se realidade e realidade virou sonho. Robespierre estava ao telefone; havia se transportado do século XVII aos nossos dias e agora me cobrava o editorial. Ainda sob efeito do terrível pesadelo e achando que poderia salvar a minha vida, prometi o editorial para o mesmo dia.

Entretanto, recuperado dos efeitos da inusitada experiência, sabia que a promessa feita ao editor teria que esperar, porque havia algumas inquietações que me incomodavam e que teriam quer ser resolvidas. Não era a coincidência entre o real e o imaginário que me preocupava, afinal sempre fizeram parte de minha existência e já me havia acostumado a premonições e coisas similares. O que importunava era a convivência de dois sonhos que se intercomunicaram e que foram a expressão de sentimentos tão díspares: a extrema serenidade e o mais intenso e pior dos pavores.

Resignado pela falta de equacionamento temporário das questões levantadas, retorno à tarefa de elaborar o editorial e me lembro de que ainda não houve tempo para levarmos até os nosso leitores a nossa mensagem de final de ano. Tenho, então, a oportunidade de agora fazê-lo.
Sustentados por uma fala social desprovida de qualquer senso de reflexão, há séculos mantemos uma tradição cultural de desejarmos aos nossos os intermináveis e repetidos votos de feliz ano novo. A expressão toma para si a tarefa quase mecânica de manter e levar adiante os costumes que nos foram legados pelos nossos antepassados. A linguagem falada, imaginada em um mimetismo circunstanciado a um cumprimento do dever, não está mais, de um modo geral, a serviço do que realmente pensamos e acaba evidenciando uma contradição entre aquilo que realmente desejamos e aquilo que exprimimos. Querendo fugir deste ambiente ingenuamente falso, reporto-me às duas situações que vivi quando dormia. Agora, substituindo os tradicionais votos de muitas felicidades, etc, etc! sonhando acordado, construo e ofereço, para reflexão de todos, dois momentos. Um primeiro, que seria a opção de uma navegação tranqüila através de verdejantes montanhas, onde os nossos atos serão aprovados pelo conjunto de regras facultativas que normalmente avaliam o que fazemos e que Foucault chama de ética. Um segundo, em que, no momento de desespero, deixamos que o instinto profissional canibalizado por uma concorrência desleal e injusta nos leve a também desrespeitar a convivência profissional por outros ultrajada e acabe, com o tempo, por nos inserir como vítimas dos jacobinos da Place de la Concorde de 1790.

A Revista Fisioterapia Brasil longe, portanto, de desejar um feliz 2005, deseja apenas uma boa reflexão, esperando que os nossos atos se identifiquem com o primeiro momento. Vivamos com dignidade e ética e sejamos felizes em 2005 , $2006,2007 \ldots$

\footnotetext{
${ }^{1}$ Friederich Gottlieb Klopstock (1724-1803), destacado poeta alemão, autor de vários hinos à natureza de poemas à amizade e ao amor.
} 